\title{
CUM AR TREBUI PLĂTIȚI MEDICII DE FAMILIE?
}

\section{Bumbuluț Călin ${ }^{1}$}

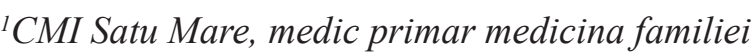

adresa de corespondență: Satu Mare, str. Bobocului UK 30,email: bumbulutcalin@yahoo.com

\author{
Motto: \\ "cu foarte puține împotriviri, probabil că vom aproba cheltuieli \\ de miliarde de dolari pentru pacing biventricular și totuşi nu știm \\ cum să plătim astfel ca o persoană să aibă propriul medic" \\ un lobbist al programului Medicare, 2004, SUA \\ "legea cererii și ofertei nu poate exista în medicină: nu poate \\ exista cerere pentru suferință și moarte" \\ un medic
}

\section{Title: How should family physicians be paid?}

Abstract: Finding on optimal payment method of family phisicians is an economical and political preocupation of all countrys with good health sistems, with the aim to ensure minimum expents and maximal eficiency. I present the payment methods of primary health care in representative health models from present, an efficient sistem for Romania also would be possible based on capitation adjusted at population characteristics, with supplimentary paymants based on furnised servicies and incentives based on achievement of definite objectives settled by the health sistem politics.

Key words: primary healthcare, family medicine, capitation, fee-for-service, blended payments.

Rezumat: Găsirea metodei optime de plată a medicilor de familie este o preocupare economică și politică a tuturor statelor cu sisteme responsabile de sănătate, cu scopul de a asigura minimum de cheltuieli la maximum de eficiență. Prezint modalitățile de plată ale asistenței primare în modele de sănătate reprezentative existente în prezent, un sistem eficient și pentru România fiind bazat probabil pe capitație ajustat la caracteristicile populației, cu plăți suplimentare bazate pe serviciile furnizate și stimulente legate de atingerea unor obiective precise fixate de politica sanitară.

Cuvinte cheie: asistență primară, medicina familiei, capitație, servicii, sisteme mixte.

Medicina bazată pe dovezi este capacitatea de a urmări, interpreta critic și adapta date dovedite prin studii statistice [1]. Această evidență ar trebui constatată și în decizia politicilor sanitare românești.

În prezent în lume sunt utilizate două sisteme de finanțare ale asistenței primare: "per capita" și "pe servicii", fiind acceptat și al treilea, o combinație a celor două. O mențiune trebuie făcută și pentru plata salarială, mai puțin utilizată. Comparația între țările europene având costuri totale scăzute ale sistemului sanitar, a dus la descoperirea unor similiarităţi fundamentale, într-un studiu multinațional european [2]: Marea Britanie, Danemarca, Norvegia, Italia și Olanda au costuri relative scăzute pentru sistemul sanitar (5-8\% din PIB), bazându-se pe o asistență primară puternică și bine 
organizată. Caracteristicile comune identificate au fost: praxisurile mici de medicină generală (cu 1500 locuitori deserviți); medici generaliști cu rolul de gate-keepers și care acoperă o gama largă de servicii, inclusiv pentru copii și gravide; acoperirea serviciilor prin sistem privat 24 ore pentru pacienții aflați pe liste; finanțarea medicinei de familie în principal pe capitație. În 1985, cheltuielile din PIB pentru sănătate în aceste țări au fost cu 20-30\% mai scăzute decât în Germania, Franța, Suedia și Austria.

Compararea generală între țări arată că o structură cu o medicină de familie comprehensivă, recunoscută și puternică, se asociază unor cheltuieli relative scăzute pentru îngrijirile pentru sănătate. Un argument suplimentar pentru această percepție este adus de studii asupra noilor evoluții în asistența primară a sistemelor, care arată o legătură cu scăderea costurilor pentru asistența secundară și terțiară [3-5].

Costurile scăzute pentru sănătate se asociază cu două caracteristici: numărul de medici de familie și nivelul lor de pregătire. Populația deservită este importantă, 1500 de locuitori la un medic pare să fie raportul adecvat [2,4]. Raportul între generaliști și specialiști trebuie să fie $1: 1 \quad[2,6,7,8,9]$. Mai mult, generaliștii trebuie să fie medici cu o experiență solidă în asistența primară, dobândită în 3-5 ani de educație medicală vocațională și o educație postuniversitară continuă, care asigură menținerea calității și costurile scăzute $[2,6]$.

În România, numărul mediu al populației deservite este de 1900 de locuitori la un medic, iar raportul între medicii de familie și alți specialiști este de 1:4,7. Rezidențiatul la noi înseamnă 3 ani de pregătire postuniversitară, fiind de multe ori o opțiune postuniversitară de necesitate și rareori vocațională.

Raportul cost eficiență al muncii generalistului, cum este demonstrat în mai multe studii, este obținut în adevăratul sens prin utilizarea mai redusă a tehnologiilor costisitoare și prin trimiteri mai puține către îngrijirile specializate. Într-un studiu [10] la King’s College Hospital în Londra, Marea Britanie, s-a demonstrat că fără a exista diferențe între rezultatele tratamentului, medicii generaliști care lucrau în departamentul de urgență al spitalului au utilizat cu aproape 50\% mai puțin serviciile de radiologie, laborator și bacteriologie, comparativ cu specialiștii din spital. Greenfield et al [11] au ajuns la concluzii similare într-un studiu comparativ al specialiștilor de medicina familiei cu medicii interniști. Experiența europeană arată că sunt atinse costuri scăzute când medicii generaliști au atribuții lărgite, incluzând îngrijirile pentru copii și gravide [2]. În Suedia, Smedby et al [12] au arătat că prin sporirea atribuțiilor asistenței primare, au scăzut costurile generale pentru sănătate.

Să încercăm sumar, să descriem câteva caracteristici ale sistemelor de plată ale asistenței primare.

\section{Plata per capita}

Plata prin capitație, legată de înregistrarea pacientului pe o listă, a fost asociată de mulți medici de familie cu o libertate clinică: MF acceptă obligația de a furniza îngrijiri pentru pacienții de pe listă și să facă ceea ce e mai bine în interesul acestora, conferind libertatea MF de a prescrie medicație, diagnostic, adresabilitate spre alți specialiști, fără spectrul necesității de a face pe plac pacientului-un lucru în mod normal desconsiderat [14]. Există și dezavantaje: capitația poate încuraja lenea întrucît plățile nu țin cont de numărul îngrijirilor, influențând stimularea îngrijirilor preventive și a bolilor cronice. Problema sistemelor bazate pe capitație este decizia: “care este îngrijirea suficientă?", pe când pentru sistemele bazate pe plata per servicii este decizia: “ce este prea mult?” [15]. Sistemele de asistență primare puternice precum cele din Marea Britanie [16] și Olanda [17], utilizează ca bază a sistemelor de plata a MF capitația. Cazurile disciplinare în Marea Britanie și Olanda sunt în mare măsură cauzate de ineficiența furnizării serviciilor la domiciliul pacienților în cazul urgențelor (percepute astfel de pacienți), în Australia, ținta acțiunilor disciplinare este excesul de servicii.

Furnizorii de asistență primară din Polonia, a căror metoda principală de finanțare a fost capitația, în cadrul unui experiment pilot, și-au luat responsabilități mai mari decât cele obișnuite pentru 
coordonarea tratamentului pacienților înscriși și pentru managementul resurselor financiare alocate prin pachetul de asigurări de sănătate. Utilizând analiza descriptivă, s-a argumentat că plata prospectivă prin capitație pentru pachete de sănătate mai mari poate încuraja integrarea spontană între furnizorii de asistență primară și secundară [23].

Un studiu multicentric [25] a demonstrat că pacienții îngrijiți de medici plătiți prin capitație au avut o indici de morbiditate și comorbiditate mai scăzuți decât cei îngrijiți de medicii plătiţi per servicii, deși ambele categorii de pacienți au avut caracteristici demografice similare. Comprehensiunea și continuitatea îngrijirilor au fost de asemeni similare în cele două grupuri. Comparativ cu pacienții îngrijiți de medicii cu un sistem de plată per servicii, cei îngrijiți de medicii cu un sistem prin capitație au avut nevoie de mai puține îngrijiri după program și de mai multe vizite la departamentele de urgență. Pe ansamblu, medicii din grupul plătit prin capitație au internat mai puțini pacienți decât medicii din grupul plătit pe servicii. În concluzie, medicii plătiți prin capitație au avut caracteristici ale practicii diferite decât cei plătiți per sevicii; aceste caracteristici par să fie pre-existente și nu neapărat datorate înregimentării în modelul cu predominanța plății per servicii.

Utilizarea îngrijirilor spitalicești este scăzută în țările în care sistemele de asigurări asigură remunerarea medicilor de familie prin capitație. În Mare Britanie de exemplu, numărul mediu de zile de spitalizare pe locuitor este 0,9 față de 2,3 în Germania. În studiul efectului plății prin capitaţie în asistența primară, mulți cercetători au descris o reducere a utilizării spitalului în îngrijirea pacientului. O legătură între plata per capita și scăderea necesității îngrijirilor psihiatrice a fost demonstrată de Hustead et al. Mai mult, un număr de autori au demonstrat că sistemul prin capitație se asociază cu o îngrijire medicală de calitate. Problema dacă plata prin capitație tinde să încurajeze tratamentul insuficient sau subdiagnosticarea, a fost investigată prin evaluarea medicilor de familie din grupuri de practică care aveau contracte per capita, respectiv per-servicii, nefiind observate diferențe semnificative relativ la tipul și numărul investigațiilor de laborator, numărul consultațiilor, sau rezultatele.

Profesia de medic generalist în Olanda presupune că plata prin capitație are un rol prevalent, pe care se bazează și standardele profesionale de îngrijire. Încercările decidenților de politică sanitară de a schimba plata prin capitație sunt în general respinse de profesie, în decursul timpului, generaliștii olandezi protejându-și cu îndârjire sistemul de plata prin capitație și excluzând orice sistem financiar părtinitor, care ar fi putut să le afecteze performanțele. Cea mai recentă (2004) propunere a ministrului sănătății olandez de schimbare a finanțării a avut ca scop introducerea unei forme de coplată a pacienților pentru asistența primită, la $25 \%$ din costurile consultației la medicul generalist și mai mult în asistența secundară. Această propunere este încă în faza inițială a deciziei politice, iar dacă va fi introdusă va fi interesant de văzut dacă această măsură financiară va "răsplăti" strategiile asistenței primare precum "așteptarea armată" [17].

În ciuda lipsei stimulilor financiari este surprinzator cât de puternică este asistența primară olandeză. Pentru mult timp specialiștii de spital au fost plătiți per serviciu. Deși acest sistem a recompensat financiar transferul pacienților în asistența secundară, ratele de prescriere și adresare către generaliștii din Olanda au fost printre cele mai bune din lume [26,27]. Mai mult, peste 80\% din cabinetele olandeze sunt informatizate în absența suportului financiar direct [17]. Aceasta poate indica faptul că sistemul de plată nu este singurul determinant în performanțele generaliștilor, iar identitatea corporatistă și structura sistemului de sănătate pot juca un rol vital. Plata generaliștilor olandezi se bazează pe un sistem binar dependent de veniturile pacienților: capitația pentru pacienții asigurați, extinsă și pentru membrii de familie care nu au venit, acoperind $70 \%$ din venit și plata per serviciu care reprezintă 30\% din venit, înțeleasă ca provenind de la pacienții neasigurați și nu din plata celor înscriși.

In Marea Britanie fondurile au crescut datorită convingerii guvernului Thatcher că piața liberă reprezintă cea mai bună cale de a atinge eficiența în sănătate. Totodată s-a stabilit că medicina generală este piatra de temelie a Sistemului Național de Sănătate (National Health System NHS) [28]. 
Remunerația se bazează în principal pe capitație (plata este dependentă de mărimea listei), suplimentată de plăți pentru servicii specifice (exemplu îngrijirile materne), precum și pentru obținerea unui anumit nivel "țintă" de servicii (un sistem complex, deși include doar vaccinările și examenul citologic cervical). De asemenea se plătește primariatul (seniority) și educația medicală continuă [16]. Metoda aplicată până în anul 2000 pentru plata medicilor generaliști din Marea Britanie printr-un sistem complex de plăți și alocări, a fost revizuită. Noile contracte cu generaliștii au intrat în funcțiune din aprilie 2004, plățile către generaliști fiind legate și de țintele de calitate pentru activitatea clinică și organizațională. Ele au fost cuplate cu creșterea fondurilor și schimbările structurale, de exemplu generaliștii nu mai sunt obligați să furnizeze servicii în afara orelor de program, iar contractele sunt încheiate mai degrabă cu grupurile de practică decât cu generaliști individuali. Extinderea de personal medical propusă și creșterea numărului de generaliști cu salariu, ar putea destabiliza sistemul și duce la efecte opuse celor așteptate. Introducerea predominantă a sistemului de alocare a resurselor prin capitație către administratorii de sănătate și trusturile de asistență primară, în concordanță cu nevoile, asigură distribuția echitabilă a fondurilor [29].

\section{Plata per servicii}

Stimularea financiară are o influență directă asupra comportamentului MF. De exemplu, în Belgia, 46\% din consultațiile medicilor de familie sunt la domiciliul pacienților [18], pe când în Olanda acestea reprezintă o mică proporție din activitatea MF. Statusul de sănătate și infrastuctura celor două țări diferă foarte puțin, astfel încât diferența poate fi explicată de stimulare prin decontarea vizitelor la domiciliu în Belgia.

Una din strategiile pentru a preveni abuzul în cazul remunerării prin plata per serviciu a constituit-o schimbarea plății pe o metodă bazată pe capitație. Efectele acestei schimbări sunt indicate de datele "utilizării" medicilor în câteva țări europene: în Marea Britanie, și cu o extindere semnificativă în Olanda și Danemarca, medicii generaliști sunt plătiți prin capitație. Î̉ Canada, Franța, Germania și Japonia, plata per servicii este în continuare singura metodă de plată. Numărul vizitelor la un medic este semnificativ mai mare în aceste ultime țări. De exemplu, între 1981-1986, rata vizitelor la medic în funcție de plata medicului este prezentată în tabelul I [13].

Tabel I. Numărul vizitelor la medicul de familie în funcție de modalitatea de plată

\begin{tabular}{|lllc|}
\hline \multicolumn{2}{r}{ Plata prin capitație } & & Plata per servicii \\
\hline Marea Britanie & 5,2 & Canada & 7,1 \\
Danemarca & 5,2 & Franța & 7,8 \\
Olanda & 5,4 & Germania & 10,8 \\
& & Japonia & 12,8 \\
\hline
\end{tabular}

Satisfacția pacienților este întărită de faptul că medicii de familie sunt în competiție. Plata per servicii poate fi inflexibilă cu privire la cine este remunerat; acest lucru ține în loc practic utilizarea corespunzătoare a asistentelor în practica generală în Australia pentru simplul fapt că aproape toate serviciile în practica generală sunt neeligibile pentru plata Medicare dacă sunt furnizate de asistente, deși pentru mai multe servicii ca medicina preventivă [19], sau îngrijirile pentru boli cronice [20], asistentele sunt mai potrivite.

O altă problemă a plății per servicii este necesitatea unei gândiri orientate spre business în asistența primară. Mulți medici doresc să practice fără a îndeplini și rolul unui "patron de magazin”. O consecință a acestei evoluții în anii 80 a fost apariția "practicii antreprenoriale", adică mai mult interes pentru profit, decât pentru servirea comunității.

"Stimularea perversă" recompensează mai bine activitatea unor clinici decât a altora, poate mai valoroase [21]. De exemplu un medic de familie care furnizează mai multe consultații scurte va câștiga mai mult decât unul cu mai puține, dar mai lungi, chiar dacă astfel de consultații mai lungi se consideră că sunt asociate unei mai bune atenții pentru prevenție și probleme psihosociale [22]. 
Exemplul tipic de sistem cu plata per servicii este cel din Franța, Germania, Canada, sau SUA. În Franta s-a negociat cu reprezentantii medicilor de familie creșterea tarifului național unic pe consultație de la 20 euro la 22 euro. Din aceasta sumă, sistemul de asigurări rambursează în 48 de ore 14,5 euro, un euro rămâne nerambursabil, restul reprezentând coplata, achitată de pacient sau sau de către asigurările private. Există și medici de familie cu tarif stabilit liber, care practică „depășiri de onorariu”, adică își stabilesc singuri tariful, dar nu sub 22 euro. Și în acest caz, sistemul rambursează tot 14,5 euro. Diferența rămâne ca și coplată, sau este rambursată de asigurările private. Pentru a lucra cu tarif liber este nevoie de un minim de ani de practică și o aprobare din partea sistemului de asigurări, dar trebuie să existe și clientela dispusă să plătească onorariul suplimentar. Există medici care au tariful de 50-60 de euro per consultație, dar există și asigurări private care rambursează până la de trei ori tariful bazal de 14,5 euro. Acesta este adevăratul sens al coplăţii într-un sistem de sănătate și nu strict pentru controlul adresabilității, cum este sugerat de administratorii sistemului sanitar românesc.

Începând cu 1 mai 2008, în grila tarifară pentru serviciile generalistului, în Franța [24] se aplică majorări ale tarifelor: în caz de deplasări între 10 și 22,6 euro, noaptea și sărbători între 19,06 și 43,50 euro, gardă între 26,5 și 55 euro, intervenții de mică chirurgie de la 51,02 la 93,72 euro, etc, observând astfel costurile incomparabile cu cele care revin în sistemele prin capitație. Trebuie subliniat că prin sistemul de plata per servicii, pacientul plătește medicului de familie întreg onorariul, urmând să recupereze o parte din sumă de la sistemul de asigurări la care este participant și restul eventual de la asigurările private de sănătate, dacă le-a contractat.

În Statele Unite sistemul sanitar are mari nerealizări și cheltuieli imense. Rezultatele sunt: inechități mari, probleme privind accesul, pierderea oportunităților pentru prevenție, îngrijire mai degraba fragmentată decât integrată, îngrijire deficitară a bolilor cronice, cheltuieli mari fără îmbunătăţiri măsurabile ale stării de sănătate, comparativ cu ceea ce ar fi de așteptat de la un sistem în care asistența primară funcționează [30]. Întradevăr, "necesitatea de a administra escaladarea costurilor medicale odată cu menținerea unui acces rezonabil la asistență reprezintă cea mai importantă încercare a politicii sanitare în SUA” [31]. În SUA se estimează că sunt peste 52.000 .000 de americani fără acces la asigurări de servicii medicale. Plata per serviciu a medicilor generaliști nu este suficientă, ea recompensând doar munca suplimentară și nu neapărat de calitate [32].

Plata combinată, sau mixul de capitaţie/servicii

Canada a optat pentru o combinație a metodelor de plată [33], iar Noua Zeelandă experimentează o varietate de modele interesante, într-o succesiune rapidă [34].

Cererea pentru servicii este infinită, iar oferta nu-i poate ține față, totuși toate sistemele încearcă să o satisfacă. Admiterea acestei evidențe accentuează presiunea pentru utilizarea resurselor într-un mod cât mai eficient posibil. Recurgerea la plata prin capitație face parte din soluțiile cele mai îndreptățite să îndeplinească sarcina. De la mijlocul anilor 90, opoziția istorică a medicilor canadieni față de capitație s-a transformat treptat. Totuşi, această adaptare reușită nu a dus la o rezolvare echitabilă: resursele financiare nu garantează funcționarea praxisului, a fost introdusă o nouă formă de competiție, totodată fiind restrânsă mobilitatea utilizatorilor. Studiile naționale confirmă faptul că plata per serviciu continuă să fie principala formă de remunerare pentru serviciile medicilor [36], cu toate acestea valoarea capitației se menține [35].

În cadrul actualului sistem de sănătate $12 \%$ din canadieni (cu variații geografice considerabile) nu beneficiază de servicii medicale [37]. Milioane de oameni nu au acces la un medic de familie, iar timpul de așteptare la departamentele de urgență este prea lung. Medicii de familie au un grad ridicat de insatisfacție datorat sarcinilor curente și condițiilor de muncă [36]. Guvernul canadian a ajuns aparent la concluzia că modalitățile de plată alternative vor rezolva aceste probleme și au intenția să implice medicii de familie în reformele asistenței primare [37,38]. Plățile alternative abordează o combinație între plata per serviciu, capitație, salar, plată pe perioadă și alte aranjamente financiare [39]. Munca în astfel de rețele cu o plată în mix cu per capita se crede că stimulează inițiativa pentru 
promovarea prevenției și managementului bolilor cronice și crește satisfacția profesională [36]. Poziția politică curentă este că o colaborare a medicilor de familie cu asistentele practiciene, farmaciști și alți profesioniști din sistem, este mai degrabă fezabilă prin modele de plată mixate și prin capitație, decât prin plata curentă per serviciu [33].

Sistemele mixte promit obținerea a ceea ce este mai bun din ambele modalități de plată, dar sunt puține dovezi [40] care să ne asigure că nu se obține cea ce este mai rău din ambele: medicii cu spirit antreprenorial vor învăța care activitate aduce cele mai mari câștiguri, iar administratorii de sănătate vor reacționa prin suprareglementarea sistemului pentru a preveni aceasta.

Intenții ale sistemului de asigurări de sănătate românesc:

-reducerea ponderii capitației de la 90\% la 50\%

-introducerea în cadrul plății per serviciu și a plății per consultație, dar și introducerea unei valori estimate la plata per serviciu (și nu garantate)

-coplata din partea pacientului de 5 de lei la fiecare consultație, dar scutirea de la contribuție personală a consultațiilor aferente plății per serviciu și cele aferente serviciilor acoperite prin capitație (adică coplata devine inutilă la orice consultație).

Desigur că acestea nu sunt toate modificările dorite de către decidenți, referindu-mă doar la cele legate de fundamentul metodei de finanțare. Urmărind evoluția finanțării asistenței primare de la introducerea sistemului de asigurări sociale de sănătate în România în 1999, putem constata că în primii șapte ani de existență a acestuia, finanțarea a scăzut continuu, ajungând la un minim istoric de 4,93\% în 2006, creșterile ulterioare nereușind să ajungă nici măcar la procentul de 8,83\% din fondul pentru sănătate din 1999 (Fig.1). Rămâne de văzut dacă în anul 2009 se va atinge un nou minim istoric, pe baza estimării bugetare de la începutul anului.

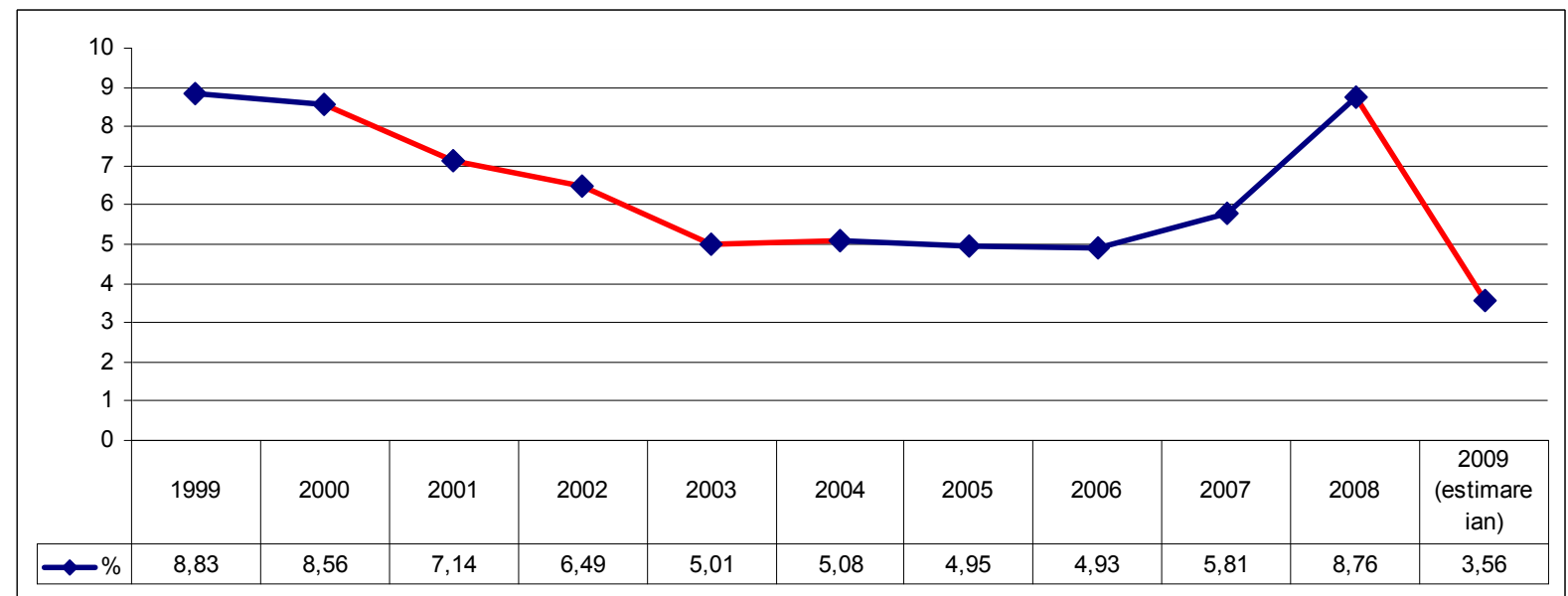

Figura 1. Evoluția procentului alocat asistenței primare din bugetul (şi ulterior fondul) de sănătate

Oricare ar fi intențiile, suma alocată asistenței primare, chiar dacă ea revine $90 \%$ prin capitație, sau dacă va fi alocată sub formă de plată per servicii, cunoaște o evoluție negativă fară precedent în scurta istorie a sistemului de asigurări românesc. $\mathrm{Nu}$ am reușit să găsesc în întreaga bibliografie citată un echivalent în alte țări al acestei evoluții, cu atât mai puțin o evoluție de la preponderența plății per capita la plata per servicii. De altfel, evoluția impusă economic a sistemelor de plată pentru asistența primară arată chiar trecerea eventuală de la plata per servicii la un sistem mixt (modelul australian, canadian).

\section{Soluția}

Medicii de familie sunt în avangarda îngrijirilor bazate pe dovezi. Ar fi bine dacă și sistemele de plată ale acestora ar fi bazate pe astfel de dovezi, dar există puține convingătoare decisiv asupra efectelor 
celor două sisteme de plată. Cele mai bune dovezi provin din analiza bazei de date Cochrane [41]: comparativ cu capitația, plata per servicii a fost asociată cu mai multe servicii furnizate, analize și trimiteri la alți specialiști, dar cu mai puține internări, iar comparativ cu salariul, plata per servicii este asociată cu mai multe servicii și cu o continuitate a îngrijirilor, dar cu prețul unei satisfacții reduse a pacienților privitor la acesul îngrijirilor.

Este probabil că organizarea asistenței primare poate fi soluția pentru costurile în sistemele de sănătate. Comparațiile între țări, precum și între sistemele de asigurări arată că o asistență primară dezvoltată se asociază cu scăderea cheltuielilor în sănătate. În acest contrext, totuși și organizarea întregului sistem sanitar are o importanță majoră, țări ca Belgia, Franța, Germania, Elveția și SUA având o proporție de medici generaliști rezonabilă și totuși costurile generale fiind ridicate [42], dar subliniez faptul că aceste țări au o plată per servicii a asistenței primare.

Studiile privind eficiența consultațiilor medicilor de familie indică că o abordare centrată pe pacient duce la cele mai bune rezultate pentru îngrijiri și pentru gradul de satisfacție al pacientului [43-46]. Poate că acest aspect al calității serviciilor- abordarea holistică a pacientului, stă la baza raportului cost-eficiență al îngrijirilor furnizate de medicii de familie.

\section{Concluzii}

Caracteristicile plății prin capitație ar trebui să fie în centrul politicilor viitoare de dezvoltare și cercetare.

Sistemele prin capitație în care medicii generaliști au o sumă fixă pentru fiecare pacient înregistrat sunt mai bune pentru controlul costurilor, pentru încurajarea continuității îngrijirilor şi pentru munca în echipă. Combinații variate între capitație și plăți pentru servicii ar putea fi cea mai bună opțiune pentru majoritatea țărilor, pe măsură ce acestea recunosc necesitatea stimulării directe a medicilor de familie, păstrând totodată controlul costurilor.

Un sistem eficient ar fi bazat probabil pe capitație ajustat la caracteristicile populației, cu plăți suplimentare bazate pe serviciile furnizate și stimulente legate de atingerea unor obiective precise fixate de politica sanitară.

Conflicte de interese declarate: autorul este președinte al Asociației Medicilor de Familie Satu Mare și membru în Consiliul Național și Comisia de Medicina Familiei a Colegiului Medicilor din România, organizații care susțin plata preponderent prin capitație a medicinei de familie.

\section{Bibliografie:}

1. Lancaster, T. Ce este medicina bazată pe dovezi?, România Update, 1(vol III),1997,6

2. Gronenwegen, P et al. Remunerating general practitioners in Western Europe. NIVEL 1987. Utrecht.

3. Sjonell, G. Relationship between use of increased primary health care and other out-patient care in a Swedish urban area. Thesis. Sundbyberg: Karolinska Institute, 1984.

4. Kekki, P. Analysis of relationship between resources and use of health services in Finland. Helsinki:

The Research Institute for Social Security of the Social Insurance Institution. 1979.

5. Wescott, LB. Hunderton. The rise and fall of a medical Camelot. N Eng J Med 1979;300: 952-6.

6. WONCA/WHO. Making medical practice and education more relevant to the peoples needs: the role of the family doctor. Hong Kong 1995.

7. Rivo, M, Satcher D. Improving access to health care through physician workforce reform. JAMA, 1992;1074-8.

8. Rosenblatt, RA. Specialist or generalist: on whom shall we base the American health care system? N Eng J Med 1995:332:1164-8. 
9. Somers, A. And who shall be the gatekeeper? The role of the primary physician in the health care system. Inquiry/volume XX, Winter 1983.

10. Dale, J, Green, J, Glucksman, Higgs, R. Providing for Primary Care: Progress in A \& E Dept of General Practice and Primary Care, King's College Hospital London SE5 9 PJ. UK.

11. Greenfield, S, Nelson, EC, Zubkoff, M, et al. Variation in resource utilisation among medical specialities and systems of care: results from the Medical Outcomes Study. JAMA 1992;267: 1624-30.

12. Smedby, B et al. Kvartersakuten i Stockholm. Student litteratur 1992. Lund.

13. Roemer, MI, National Health Systems of the World, vol II, The Isues, Oxford University Press US, 1993,127.

14. Little, P, Dorward, M, Warner, G, et al. Importance of patient pressure and perceived pressure and perceived medical need for investigations, referral, and prescribing in primary care: nested observational study. BMJ 2004;328:444.

15. Van Weel,C, Del Mar,CB. How should GPs be paid?, MJA, 2004;181(2):98-99.

16. Weller, DP, Maynard, AM. How general practice is funded in the United Kingdom. Med J Aust 2004;181:109-110.

17. Van Weel, C. How general practice is funded in The Netherlands. Med J Aust 2004;181:110-111

18. de Maeseneer J, De Prins L, Heyerick JP. Home visits in Belgium: a multivariate analysis. Eur J Gen Pract 1999;5:11-14.

19. Charlton, I, Charlton, G, Broomfield, J, Mullee, MA. Audit of the effect of a nurse run asthma clinic on workload and patient morbidity in a general practice. Br J Gen Pract 1991;41:227-231.

20. Effectiveness of health checks conducted by nurses in primary care: final results of the OXCHECK study. Imperial Cancer Research Fund OXCHECK Study Group. BMJ 1995;310:1099-1104.

21. Bollen, MD. Recent changes in Australian general practice. Med J Aust 1996;164:212-215.

22. Howie, JGR, Porter, AMD, Heaney, DJ, Hopton, JL. Long to short consultation ratio: a proxy measure of quality of care for general practice. Br J Gen Pract 1991;41:48-54.

23. Kowalska, K. Managed care and a process of integration in health care sector: A case study from Poland. Health Policy 2007 Jun 13.

24. http://www.mgfrance.org/content/view/660/1072/

25. Glazier, RH, Klein-Geltink, J, Kopp, A, Sibley, LM. Capitation and enhanced fee-for-service models for primary care reform: a population-based evaluation. [Comparative Study, Journal Article, Multicenter Study, Research Support, Non-U.S. Gov't] CMAJ 2009;180(11):E72-81.

26. Boerma, WGW, Fleming, DM. The role of general practice in primary health care. London: The Stationery Office, 1998.

27. Starfield, B. Is primary care essential? Lancet 1994;344:129-133.

28. Moon, G, Mohan, J, Twigg, L, et al. Catching waves: the historical geography of the general practice fundholding initiative in England and Wales. Soc Sci Med 2002;55:2201-2213.

29. Lewis, R, Gillam, S. Doctors ' pay. What seems to be the trouble?, Health Serv J 2000;110(5715):2830.

30. Phillips, RL Jr, Starfield, B. Why does a US primary care physician workforce crisis matter? Am Fam Physican 2003;68:1494-1505.

31. Mello, MM, Studdert, DM, Brennan, TA. The pharmaceutical industry vs Medicaid-limits on state initiatives to control prescription-drug costs. N Engl J Med 2004;305:608-613.

32. Green,LA. Finantarea asistenței primare în Statele Unite. MJA 2004;181(2):113-114

33. Martin,CM, Hogg, WE. How family physicians are funded in Canada. Med J Aust 2004;181:111-112.

34. Malcolm, LA. How general practice is funded in New Zealand. Med J Aust 2004;181:106-107.

35. Brunelle, Y, Bergman, H. Capitation, efficience et rationnement, Ruptures, 1999;6(2):270-288 
36. The Janus Project: family physicians meeting the needs of tomorrow's society. Results of the National Family Physician Surveys, 1997/98 and 2001. Regional reports. Available at: www.cfpc.ca/English/ cfpc/research/janus\%20project/ (accessed Mar 2004).

37. Romanow, RJ. Building on values: the future of health care in Canada - final report. Saskatoon, Saskatchewan: Commission on the Future of Health Care in Canada, 2002. Available at: www.hc-sc. gc.ca/english/care/romanow/hcc0086.html (accessed Jun 2004).

38. Mable, AL, Marriott, J. Sharing the learning. The health transition fund. Synthesis series. Primary health care. Ottawa: Health Canada, 2002.

39. Alternative payments and the national physician database (NPDB): the status of alternative payment programs for physicians in Canada 1999/2000. Ottawa: Canadian Institute for Health Information, 2001.

40. Giuffrida, A, Gosden, T, Forland, F, et al. Target payments in primary care: effects on professional practice and health care outcomes. In: The Cochrane Library, Issue 2, 2004. Chichester, UK: John Wiley \& Sons, Ltd.

41. Gosden, T, Forland, F, Kristiansen, IS, et al. Capitation, salary, fee-for-service and mixed systems of payment: effects on the behaviour of primary care physicians [Cochrane review]. In: The Cochrane Library, Issue 2, 2004. Chichester, UK: John Wiley \& Sons, Ltd.

42. World Development Report 1993, Investing in health. World Bank. Oxford University Press, New York.

43. Bass, $\mathrm{M}$ et al. The physician's actions and the outcome of illness in family practice. $\mathrm{J}$ Fam Pract 1986;23:43-7.

44. Henbest, R, Stewart, MA. Patient-centredness in the consultation. 1: A measurement, Fam Pract 1989;6:249-53.

45. Henbest, R, Stewart, M. Patient-centredness in the consultation.2. Does it really make a difference? Fam Pract 1990;7:28-33.

46. Henbest, R. Patient-centredness: Is it applicable outside the west? Its measurement and effect on outcome. Fam Pract 1992;9:311-7.

alte informații utile în legătură cu ideile exprimate pt fi găsite în:

47. Sjonell, G. Organised Family Medicine: The Key Issue To Cost-Effective Healthcare, The Singapore Family Physician,1997; Vol. XXIII,No. 2

48. World Health Organization, Regional Office for Europe, Copenhagen. Development of General Practice in the countries of Central and Eastern Europe, report on a WHO Working Group, 1992, pag16,19, http://whqlibdoc.who.int/euro/-1993/EUR_ICP_PHC_352.pdf

49. Starfield, B. Is primary care essential? Lancet 1994;344:1129-33.

50. Nuttey, P, Clancy, CM, Franks, C. Gatekeeping revisited: Protecting patients from over treatment. N Eng J Med, 1992;327:424-9.

51. Dietrich, AJ, Nelson, EC, Kirk, JW, Zubkoff, M, O'Conner, GT. Do primary care doctors actually manage care their patients fee-for-service care? JAMA, 1988;250:3145-9.

52. Roland, M, Morris, R. Are referrals by general practitioners influenced by the availability of consultants? BMJ. 1988;297:599-600.

52. Wasson, JH, Sauvigne, AK, Mogielnicki, RP, et al. Continuity of medical care in elderly men JAMA. 1984;252:2413-7.

53. Manning, WG, Leibowitz, A, Goldberg, GA, Rogers, WH, Newhouse, JR. A controlled trial of the effects of a prepaid group practice on use of services. N Eng J Med. 1984;310:1505-10.

54. Hornbrook, MC, Berki, SE. Practice and payment method: effects on cost, use, quality and access. Med Care 1985;23:484-511.

55. Hayes, TM, Harries, J. Randomised controlled trial of routine hospital clinic care versus routine general practice care for type II diabetics Br Med J 1984;289:728-30. 
56. Singh, BM, Holland, MR, Thorn, PA. Metabolic control in diabetes in general practice clinics: comparison with a hospital clinic. Br Med J 1984;289:726-8.

57. Shear, C et al. Provider continuity and quality of medical care. Med Care. 1983;21:1204-10.

58. Dietrich, AJ, Marton, K. Does continuous care from a physician make a difference? J Fam Pract 1982;15:929-36.

59. Hakansson, A. Epidemiology of pregnancy and infancy. Population-based studies in primary health care. Thesis. Dalby 1989, Lunds Universitet.

60. Committee on the cost of medical care. Medical care for American people. (Chicago CCMC, 1932) Reprinted by the US Dept of Health, Education and Welfare, Public Health Service, Washington DC 1970.

61. Clancy, CM, Hillner, BE. Physicians as gatekeepers: the impact of financial incentives. Arch Intern Med 1989;149:917-29.

62. Epstein, A, Begg, CG, McNeil, BJ. The use of ambulatory testing in prepaid and fee-for-service group practices: relation to perceived profitability. N Eng J Med. 1986;314:1089-94.

63. Leape, LL, Brennan, TA, Laird, N. The nature of adverse events in hospitalised patients - results of the Harvard Medical Practice Study 11. Eng J Med. 1991;324:377-84.

64. Franks, P, Clancy, C, Nutting, P. Gatekeeping revisited - protecting patients from overtreatment. Eng J Med 1992;327:424-7.

65. Fishbone, M, Starfield, B. Child health care in the US. A comparison of paediatricians and general practitioners. Eng J Med. 1981;305:552.56.157.

66. Moloney, TW, Rogers, DE. Medical Technology: A different view of the contentious debate over costs. Eng J Med 1979;301:1413-9.

67. Paxton, HT. Generalist vs Specialists: The battle for patients heats up. Med Economy. 1983:200-9.

68. Siu, AL, Leibowitz, A, Brook, RH, et al. Use of the hospital in a randomised trial of prepaid care. JAMA 1988;259:1343-6.

69. Hornbrook, M Berki, S. Practice mode and payment method. Med Care 1985;23:484-511.

70. Arnold, RJ, Debrock, LW, Pollard, JW. Do HMO's produce specific services more efficiently? Inquiry 1984;21:243.

71. Hillman, A, et al. How do financial incentives affect clinical decisions and financial performance of health maintenance organisations? N Eng J Med 1989;321:86-91.

72. Donabedian, A. The quality of care in a health maintenance organisation. Inquiry 1983;20:218.

73. Cunningham, FC, Williamson, JW. How does the quality of care in HMO's compare to that in other settings? An analytic literature revue. 1958-1979. Group Health J 1980;1:4.

74. Brook, R, et al. Quality of ambulatory care. Med Care 1990;28:392-433.

75. Udvarhelyi, S, et al. Comparison of the quality of ambulatory care for fee-for-service and prepaid patients. Ann Intern Med. 1991;115:394-400.

76. Murray, P, et al. Ambulatory testing for capitation and fee-for service patients in the same practice setting. Med Care 1992;30:252-61.

77. Dale, J, Lang, H, Roberts, JA, Green, J, Glucksman, E. Cost effectiveness of treating primary care patients in accident and emergency: a comparison between general practitioners, senior house officers, and registrars. BMJ 1996;312:1340-4.

78. Badia, JG. General practice/family medicine in the new Europe - changes and challenges. Allmanmedicin 1996;17(18):22-25.

79. McWhinney, IR. A textbook of family medicine. 2nd ed. Oxford: Oxford University Press, 1997.

80. Pollock, A, Dunnigan, M, Gaffney, D, et al. The private finance initiative: planning the "new" NHS: downsizing for the 21st century. BMJ 1999;319:179-184. 
81. Dusheiko, P, Gravelle, H, Jacobs, R, Smith, P. The effects of budgets on doctor behaviour: evidence from a natural experiment. Technical Paper 26. York: Centre for Health Economics, University of York, 2003. Available at: www.york.ac.uk/inst/che/tech.htm (accessed Jun 2004).

82. Gosden, T, Sibbald, B, Williams, J, et al. Paying doctors by salary: a controlled study of general practitioner behaviour in England. Health Policy 2003;64:415-423.

83. Maynard, A, Bloo,r K. Do those who pay the piper call the tune? Health Policy Matters Issue 8, October 2003. University of York. Available at: www.york.ac.uk/healthsciences/pubs/hpmindex.htm (accessed Jun 2004).

84. Levit, K, Smith, C, Cowan, C, et al. Health spending rebound continues in 2002. Health Affairs 2004;23(1):147-159.

85. 2004 FACTS about family practice. Table 8: Practice profile of family physicians by family practice residency completion, January 1, 2004. Available at: www.aafp.org/x763.xml (accessed Jun 20 04).

86. DeVoe, J, Fryer, GE, Hargraves, L, et al. Does career dissatisfaction affect the ability of family physicians to deliver high-quality patient care? J Fam Pract 2002;51:223-228.

87. Future of Family Medicine Project Leadership Committee. Martin JC, Chairman. The future of family medicine: a collaborative project of the family medicine community. Ann Fam Med 2004;2 Suppl:S3-S32.

88. Hill, E. Making sense of preventive medicine coding. Fam Pract Manag 2004;11:49-54.

89. Leatherman, S, Berwick, D, Iles, D, et al. The business case for quality: case studies and an analysis. Health Affairs 2003;22(2):17-30.

90. Galvin, R. Purchasing health care: an opportunity for a public-private partnership. Health Affairs 2003;22(2):191-195.

91. Wallack, SS, Tompkins, CP. Realigning incentives in fee-for-service medicare. Health Affairs 2003;22(4):5970.

92. Weil, A. There's something about Medicaid. Health Affairs 2003;22(1):13-30.

93. Dale, S, Brown, R, Phillips, B, et al. The effects of cash and counseling on personal care services and medicaid costs in Arkansas. Health Affairs 2003;W3:566-575.

94. Finkelstein, EA, Flebelkorn, IC, Wang, G. National medical spending attributable to overweight and obesity: how much and who's paying? Health Affairs 2003;W3:219-226.

95. Green, LA, Graham, R, Frey, JJ, Stephens, GG, editors. Keystone III. The role of family practice in a changing health care environment: a dialogue. Washington, DC: The Robert Graham Center, American Academy of Family Physicians, 2001.

96. Results of the CMA's 2003 Physician Resource Questionnaire. Available at: www.cmaj.ca/cgi/data/169/7/701/ DC1/25 (accessed Mar 2004).

97. Green, LA, Yawn, BP, Lanier, D, Dovey, SM. The ecology of medical care revisited. N Engl J Med 2001;344:2021-2024.

98. Reviewing Practice Incentive Program and Enhanced Primary Care Items: Preliminary Report on Stages 3, 4 and 5. Available at: www.health.gov.au/redtape/pip_epc.htm (accessed Jun 2004).

99. Green, LA. How family physicians are funded in the United States. Med J Aust 2004;181:113-114.

100. Remuneration and related matters. In: AMA policy, resolutions and policy statements. Canberra: Australian Medical Association, 2003;55-65.

101. Investing in general practice. The new general medical services contract. February 2003. Available at: www.bma.org.uk/ap.nsf/Content/NewGMSContract (assessed May 2004).

102. de Maeseneer, J, Bogaert, K, De Prins, L, Groenewegen, P. A literature review. In: Brown S, editor. Physician funding and health care systems - an international perspective. London: Royal College of General Practitioners, 1999;18-32.

Alte surse: rapoartele de activitate ale Casei Naționale de Asigurări de Sănătate pe 1999, 2000, 2001, 2002, 2003,2004, 2005, 2006, 2007, 2008; Nota Ministerului Sănătății cu privire la definirea pachetului general de servicii medicale din sistemul asigurărilor sociale de sănătate şi introducerea tichetelor pentru sănătate 